
Hanna SPOSÓB ${ }^{1}$

\title{
PRACTICAL APPLICATION OF LYSOZYME AND ITS CONTENT IN CHICKEN EGG ALBUMEN
}

\author{
Department of Breeding Methods and Poultry Breeding, Siedlce University of Natural Sciences \\ and Humanities, Poland \\ ${ }^{1}$ Department of Health Sciences, Siedlce University of Natural Sciences and Humanities, Poland
}

\begin{abstract}
The aim of the study was to analyse the albumen of eggs of Ross 308 hens with particular focus on lysozyme and its potential applications. The research material comprised eggs from parent stock of Ross 308 meat chickens. A total of 200 eggs were assessed. Egg weight and albumen characteristics were assessed and lysozyme content in the egg white was determined. A meta-analysis showed that egg characteristics differ in hens of different genetic groups. Our research concerns meat chickens. In comparison to laying hens, eggs from these hens had a greater share of yolk and shell and a smaller share of albumen. The combined lysozyme content of both albumen fractions was about $0.3 \%$. The eggs of laying hens can be assumed to have slightly higher lysozyme content, which may be significant in terms of the source of its acquisition for the needs of industry.
\end{abstract}

Key words: chicken egg white, lysozyme.

\section{INTRODUCTION}

Eggs play a significant role in the human diet. They are an excellent and affordable source of the highest quality proteins and have very high concentrations of nutrients (Abeyrathne et al. 2013; Szablewski et al. 2013). The egg contains proteins, nearly all vitamins (except vitamin $\mathrm{C}$ ), B vitamins, including the valuable vitamin $\mathrm{B}_{9}$ (folic acid), fat-soluble vitamins, carotenoids, choline, niacin, which regulates blood sugar and cholesterol levels, and lecithin, which is essential for heart and brain function. Another advantage of eggs is their high content of minerals, including zinc, calcium, phosphorus and iron. Moreover, they are one of the few food products that contain natural selenium and iodine (Szablewski et al. 2013), as well as folate, which is important in the human diet (Bielecka et al. 2015).

Chicken egg white has high biological value. It is treated as a standard for assessing the value of other proteins, because it contains large amounts of essential amino acids, i.e. those that must be supplied with food. Egg white contains lysozyme, an enzyme with bactericidal and antiviral properties, as well as avidin, which forms a complex with biotin (vitamin H). To avoid vitamin $\mathrm{H}$ deficiency, eggs should not be eaten raw (Rachwał 2006). Egg lipids consist mainly of oleic and palmitic acid glycerides, essential fatty acids (EFA), phospholipids

Corresponding author: Dorota Banaszewska, Department of Breeding Methods and Poultry Breeding, Siedlce University of Natural Sciences and Humanities, Bolesława Prusa 14, 08-110 Siedlce, Poland e-mail: dorota.banaszewska@uph.edu.pl 
(including lecithin) and cholesterol. Lecithin, due to its emulsifying properties, is referred to as a 'fat burner' (Rachwał 2006). The pigments present in the yolk play a role in the human body. Xanthophyll prevents deposits on artery walls, while lutein protects the eyes from the harmful effects of UVA and UVB radiation (Michalak and Mróz 2003).

Consumers are showing increasing interest in organically produced eggs. Organic eggs have more favourable physical parameters, i.e. better shell strength, greater weight, higher content of vitamins and unsaturated fatty acids, and a more intense yolk colour. However, irrespective of the system in which hens are raised, eggs are one of the most valuable food products, and due to their versatile properties, they are widely used not only in the food industry, but for other purposes as well (Kijowski et al. 2013). The development of technology and individual sciences in the field of biochemistry has provided detailed knowledge of egg components, including proteins which are also used in the cosmetics and pharmaceutical industries. One such protein is lysozyme, referred to as a "natural antibiotic" (Gołąb and Warwas 2005). Lysozyme was one of the first egg proteins to be isolated and used by industry (Abeyrathne et al. 2013). Previous research on this enzyme has not fully explained all of its possible functions, which makes lysozyme an interesting subject of research (Gajda and Bugla-Płaskońska 2014).

The composition and quality of table eggs is determined by genetic factors, where the origin of the hens plays a key role, as well as by environmental factors: the light programme, rearing method and diet of the hens (Hocking et al. 2003; Sokołowicz and Krawczyk 2004; Silversides and Budgell 2004; Basmacioglu and Ergul 2005; Hunton 2005; Czaja and Gornowicz 2006; Krawczyk 2009). Egg quality is also affected by the age and physiological state of the hens (Gilewski and Wężyk 2010). Hence the aim of this study was to analyse the egg albumen of Ross 308 hens, with particular focus on lysozyme and its potential applications.

\section{MATERIAL AND METHODS}

The research material consisted of eggs from parent stock of Ross 308 meat chickens. The birds were kept in enclosed housing in accordance with the requirements given in "Instructions for raising a Ross 308 flock" (Aviagen 2012). The microclimate conditions of the chicken houses were in accordance with accepted standards. The chickens were fed a complete compound feed consistent with Poultry Nutrition Standards (Smulikowka and Rutkowski 2005). The birds were exposed to 14 hours of light per day.

A total of 200 eggs were assessed. The weight of all eggs and their individual components (albumen, yolk and shell) were determined. Based on the data, the percentage share of each morphological component of the egg in the weight of the entire egg was calculated.

The following albumen characteristics were calculated as well:

- thick albumen height - after breaking the egg against a table, through contact between an EQM sensor and the surface of the thick albumen. Based on the thick albumen height and weight of the egg, Haugh units were calculated according to the following formula (Williams 1992):

$$
\mathrm{HU}=100 \log \left(\mathrm{Hb}+7.6-1.7 \mathrm{ew}^{0.37}\right)
$$


where:

$\mathrm{Hb}$ - thick albumen height,

ew - egg weight measured with an Ohaus electronic scale to within 0.01g;

- concentration of hydrogen ions $(\mathrm{pH})$ with a $\mathrm{CP}-251 \mathrm{pH}$ meter.

In addition, lysozyme content was determined in the egg white according to Kijowski and Leśnierowski (1999).

Statistical analysis of the data included calculation of means and standard deviations (STATISTICA version 10.0, StatSoft Inc., PL). A meta-analysis was used to compare the data with results reported by other authors according to chicken genotype.

\section{RESULTS AND DISCUSSION}

The Table 1 presents our own results regarding selected components of the eggs of Ross 308 hens, with particular emphasis on lysozyme, as well as the results of other authors who analysed these features in various genetic groups of hens. The data in the table confirm differences in egg characteristics depending on the genetic origin of the hens. Statistical comparison of the results is not possible and statistical differences cannot be established, as this was not our own research and furthermore, the eggs came from hens of different ages kept in different systems. However, it can be conclusively stated that egg characteristics differ in hens of different genetic groups.

Table 1. Selected egg traits depending on chicken genotype

\begin{tabular}{|c|c|c|c|c|c|c|}
\hline \multirow{4}{*}{\multicolumn{2}{|c|}{ Trait }} & Our results & $\begin{array}{c}\text { Lewko and } \\
\text { Gornowicz } \\
(2016)\end{array}$ & $\begin{array}{l}\text { Lewko and } \\
\text { Gornowicz } \\
(2015)\end{array}$ & $\begin{array}{c}\text { Krawczyk } \\
\text { and } \\
\text { Gornowicz } \\
(2010) \\
\end{array}$ & $\begin{array}{c}\text { Lewko and } \\
\text { Gornowicz } \\
(2009)\end{array}$ \\
\hline & & \multicolumn{5}{|c|}{ Genotype } \\
\hline & & Ross 308 & $\begin{array}{c}\text { ¿New } \\
\text { Hampshire x } \\
\text { qBarred Rock } \\
\end{array}$ & $\begin{array}{l}\text { JK-64 x } \\
\text { 甲A-82 }\end{array}$ & Messa 45 & S-55 \\
\hline & & \multicolumn{5}{|c|}{ mean \pm SD } \\
\hline \multicolumn{2}{|c|}{ Albumen weight [g] } & $35.01 \pm 5.29$ & $37.22 \pm 2.99$ & $33.70 \pm 3.48$ & - & $\begin{array}{c}41.14 \pm \\
3.54 \\
\end{array}$ \\
\hline \multicolumn{2}{|c|}{ Albumen height [mm] } & $6.42 \pm 1.35$ & $6.36 \pm 1.10$ & $4.67 \pm 1.35$ & $8.62 \pm 1.91$ & $6.91 \pm 1.03$ \\
\hline \multicolumn{2}{|l|}{ Haugh units } & $78.09 \pm 8.79$ & $78.98 \pm 7.69$ & $64.20 \pm 13.44$ & $90.6 \pm 10.57$ & $\begin{array}{c}80.04 \pm \\
7.23 \\
\end{array}$ \\
\hline \multicolumn{2}{|c|}{ Albumen pH } & $8.93 \pm 0.15$ & $9.07 \pm 0.05$ & - & - & $7.78 \pm 0.44$ \\
\hline \multirow{2}{*}{$\begin{array}{l}\text { Lysozyme } \\
\text { activity } \\
{[\mathrm{U} / \mathrm{ml}]}\end{array}$} & thin albumen & \multirow{2}{*}{ 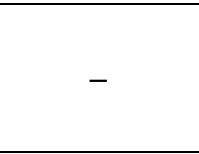 } & $\begin{array}{c}119.772 \pm \\
16.860 \\
\end{array}$ & $\begin{array}{c}95.062 \pm \\
5809\end{array}$ & \multirow{2}{*}{-} & \multirow{2}{*}{104.313} \\
\hline & thick albumen & & $76.926 \pm 13.250$ & $\begin{array}{c}48.737 \pm \\
6462 \\
\end{array}$ & & \\
\hline \multirow{2}{*}{$\begin{array}{l}\text { Lysozyme } \\
\text { [\%] }\end{array}$} & thin albumen & \multirow{2}{*}{$0.282 \pm 0.15$} & \multirow{2}{*}{-} & $0.45 \pm 0.03$ & \multirow{2}{*}{$0.39 \pm 0.05$} & \multirow{2}{*}{-} \\
\hline & thick albumen & & & $0.23 \pm 0.03$ & & \\
\hline \multicolumn{7}{|c|}{ Percentage share of egg weight } \\
\hline \multicolumn{2}{|l|}{ Shell } & $12.04 \pm 1.22$ & $10.75 \pm 0.75$ & - & $10.1 \pm 0.77$ & - \\
\hline \multicolumn{2}{|l|}{ Albumen } & $56.22 \pm 5.10$ & $60.56 \pm 2.77$ & - & $66.4 \pm 2.62$ & $\begin{array}{c}60.23 \pm \\
4.95\end{array}$ \\
\hline \multicolumn{2}{|l|}{ Yolk } & $32.18 \pm 3.10$ & $27.44 \pm 2.81$ & - & $23.4 \pm 1.99$ & - \\
\hline
\end{tabular}

$\overline{\mathrm{X}}$ - mean, SD - standard deviation. 
Our research was conducted on meat hens. Analysis of the data shows that in comparison to laying hens, the eggs from these hens had a greater share of yolk and shell and a smaller share of albumen. The combined lysozyme content in both albumen fractions was about $0.3 \%$, so slightly less than that reported by Krawczyk and Gornowicz (2010). The eggs of hens of laying lines can be assumed to have slightly higher content of lysozyme, which may be significant in terms of the source of its acquisition for the needs of industry.

Of all the bioactive components of the chicken egg, only lysozyme is on the list of permissible food additives. It is toxicologically safe because it also occurs in the human body. It has properties that are desirable in substances used for preserving food and is considered harmless. Many studies have shown that lysozyme isolated as a pure enzyme may prolong the shelf life of many food products. In order to extend its activity to Gram-negative bacteria, lysozyme must be modified in various ways and combined with other substances (Gołąb and Warwas 2005, Bioactive egg compounds 2007). Owing to its alkalinity, lysozyme forms complexes with other proteins such as ovomucin or biopolymers. The physicochemical state of such a complex with ovomucin is an indicator of egg freshness, because it is responsible for the gel structure of the albumen (Trziszka 2000).

Lysozyme ( $\mathrm{N}$-acetyl-muramylhydrolase, E.C.3.2.1.17) is also known as muramidase. This low-molecular-weight enzyme is present in virtually all tissues and secretions of humans and animals. In addition, it has been isolated from some plants, bacteria and bacteriophages (Leśnierowski and Borowiak 2012). Lysozyme is a very important component of egg white with respect to defence mechanisms.

The enzyme was discovered in 1922 by Scottish physician and microbiologist Alexander Fleming, who was conducting research on bactericides. While he was suffering from an infection, he observed that his nasal discharge, having accidentally fallen on a plate with a bacterial culture, dissolved a yellowish colony. He decided to conduct an experiment and obtained the same lysis effect on bacterial colonies using other secretions, such as saliva, tears, milk or serum. The bacteriolytic substance he had discovered, naturally occurring in the human body, he called lysozyme. The enzyme constitutes about $3.5 \%$ of the weight of proteins in the chicken egg. In egg white, it creates a natural barrier protecting the egg contents against various kinds of microorganisms (Gołąb and Warwas 2005).

Lysozyme has antibacterial properties. It hydrolyses glycosidic bonds occurring in the bacterial cell wall. The impaired wall cannot withstand the osmotic pressure inside the bacterium and breaks. It mainly provides protection against Gram-positive bacteria, because in this case peptidoglycan - the substrate of the enzyme - is directly exposed to the effect of lysozyme. Gram-negative bacteria, on the other hand, are protected against the effect of lysozyme by a cell wall containing additional components such as polypeptides and lipopolysaccharides, which form a protective layer that is difficult for the enzyme to overcome. Lysozyme also has the ability to hydrolyse glycosidic bonds in chitin (Gołąb and Warwas 2005).

The polypeptide chain of this enzyme is composed of 129 amino acid residues, and its spatial arrangement is determined by four disulphide bridges. Lysozyme is alkaline, which allows it to form complexes with other proteins, such as ovomucin and biopolymers. The lysozyme-ovomucin complex, for instance, is responsible for the gel consistency of the 
albumen, whose physicochemical state is an indicator of egg freshness. The proteins contained in eggs perform very important functions and have a variety of applications, from medicine to storage and improving the quality of dishes (Gołąb and Warwas 2005).

Lysozyme has properties that make it useful for food preservation. Its concentration in egg white is on average $3.2 \mathrm{mg} / \mathrm{ml}$, in human colostrum about $65 \mu \mathrm{g} / \mathrm{ml}$, and in cow's milk $0.13 \mu \mathrm{g} / \mathrm{ml}$. Hence the use of this substance, which occurs naturally in many food products, cannot be a toxicological risk for humans in an amount that does not exceed 10-100 $\mu \mathrm{g} / \mathrm{ml}$. In recent years, new examples of the antibacterial mechanisms of lysozyme, independent of its hydrolytic activity, have been reported (Masschalck et al. 2001).

In 1992 experts from the Joint FAOMHO Expert Committee on Food Additives recognized muramidase as a safe agent and permitted its use in food production and preservation (Kijowski and Leśnierowski 1995). Lysozyme is used as an additive in processed foods and as a component of solutions for spraying or soaking finished food products (Borowiak and Leśnierowski 2012). In Japan, methods have been developed for preserving fresh fruit, fish, meat and vegetables by coating their surface with lysozyme. Oysters and shrimp are stored at low temperatures after being coated with a solution of muramidase and $\mathrm{NaCl}$. Preservation using lysozyme has been developed for typical Asian dishes, such as sushi, Japanese salad and Chinese dumplings (Kijowski and Leśnierowski 1995).

The most studies related to the potential use of lysozyme have been conducted in the area of cheese production. Muramidase is used to eliminate a large number of butyric acid bacteria (mainly Clostridium tyrobutyricum) in the production of ripened cheeses. The enzyme does not affect the production or ripening processes, while it improves sensory characteristics (Borowiak and Leśnierowski 2012). Lysozyme is also used in the production of Edam cheese. Using lysozyme with activity of $500 \mathrm{U} / \mathrm{ml}$ (corresponding to the addition of chicken egg white in the amount of about $0.6 \%$ ), a positive microbiological result was obtained. Chicken egg white and pure enzyme showed similar effectiveness (Gajda and Bugla-Płaskońska 2014).

Lysozyme is also used to control the presence of lactic acid bacteria in wine and beer production (Daeschel et al. 1999). Muramidase is also a potent inhibitor of hiochi bacteria (Lactobacillus heterohiochi and Lactobacillus homohiochii) in sake (Yajima 1968).

In meat processing, preservation procedures involving lysozyme are used for Viennese, beef and salami sausages (in the form of added egg white, a coating agent, or a component of solutions in which the casings and finished products are soaked). Research results confirm that the addition of muramidase to meat products reduces the degree of postproduction contamination, and also significantly prolongs the shelf life of the products in cold storage (Malicki et al. 2003). In the case of beef sausage, the best results were obtained by adding muramidase to a curing mix containing sodium chloride and sodium nitrite (Kijowski and Leśnierowski 1995).

By incubating eggs in their shells or egg white alone at $40^{\circ} \mathrm{C}$, oligomerization of lysozyme can be achieved (Leśnierowski 2009; Leśnierowski and Borowiak 2012). In this form, lysozyme loses some of its hydrolytic activity, while it has a much stronger antibacterial effect on Gram-positive bacteria, in addition to an increased range of activity against Gram-negative bacteria (which include many pathogenic bacteria). The dimerization of lysozyme 
results in new activity involving the exposure of a hydrophobic region in the molecule. This increases the ability of lysozyme to penetrate the membrane, which explains its increased efficacy against Gram-negative bacteria (Leśnierowski 2009; Leśnierowski and Borowiak 2012).

Research results show that irrespective of the method of lysozyme modification, the preparations obtained show increased biological antimicrobial activity and an increased range of antibacterial properties. This enables much better use of lysozyme in the food industry for production and storage (Leśnierowski and Borowiak 2012).

Lysozyme has also been used in human and veterinary medicine. Muramidase is used to treat viral, bacterial and fungal infections. Medicines containing lysozyme in the form of sticks or ointments can be applied to the mucous membranes of the throat, mouth or eyes or to the skin. Lysozyme is used to produce medicinal chewing gums for treatment of oral and periodontal disease. Due to its analgesic properties, muramidase is used in cancer treatment or to enhance antibiotic therapy or the effect of corticosteroids, antiseptics and proteolytic enzymes (Gołąb and Warwas 2005).

In combination with $\beta$-lactam antibiotics, lysozyme has a strong bactericidal effect, so treatment with these substances effectively inhibits bacteraemia and helps to avoid sepsis (Liang et al. 1998). Peptides derived from muramidase, despite having no enzymatic activity, are bacteriostatic. They have aroused special interest due to their low molecular weight and the lack of allergic reaction following their use in preparations for medicinal use. This reaction can be observed in response to the use of muramidase. Mine et al. (2004) developed peptides that inhibit the development of two types of bacteria, Gram-negative Escherichia coli K-12 and Gram-positive Staphylococcus aureus. Muramidase has properties that can be exploited in targeted transport of drugs to the kidneys. Lysozyme alone as a low-molecularweight protein or in combination with certain drugs is very easily filtered through the renal glomeruli. It is then broken down in the lysosomes of the proximal tubule cells. The use of this combination of muramidase with a specific drug makes it possible to control the release rate of the drug in the kidneys. Low-molecular-weight proteins are only deposited in renal cells, which helps to avoid harmful consequences that might occur in the case of an effect on other cells of the human body. Targeted transport of drugs to the kidneys is beneficial to treatment of kidney disease, as well cardiovascular disease (Haas et al. 2002).

The level of lysozyme in humans and animals can be a diagnostic indicator of pathological changes. Determination of serum lysozyme levels is useful for the diagnosis of bacterial or viral meningitis. The amount of muramidase obtained from faeces is used as an indicator of pathological changes in the intestines. High content of this enzyme in the faeces of people over 40 may be evidence of anal cancer (Kijowski and Leśnierowski 1995). Muramidase, like some other proteins isolated from hen's eggs, such as ovomucin, avidin and cystatin, is used in ELISA immunoassays (Gołąb and Warwas 2005).

Previous studies by many authors indicate that under certain conditions lysozyme may show properties other than antibacterial effects. New possibilities for using lysozyme can be obtained by modifying it to obtain dimers and higher oligomers of lysozyme, which have a wider range of potential uses (Leśnierowski 2007, 2009). 
Research on the modification of lysozyme to obtain new and specific properties is still ongoing. These studies show that irrespective of the method of modification, preparations obtained in this manner exhibit increased biological antimicrobial activity as well as an increased spectrum of antibacterial activity. This broadens the potential use of muramidase in the food industry for food preservation. All studies carried out so far on the modification of lysozyme have concerned the enzyme after its isolation from egg white. It seems interesting to investigate whether lysozyme can also be modified in its natural environment, i.e. in egg white (Cegielska-Radziejewska et al. 2003, 2009; Leśnierowski 2009).

\section{CONCLUSIONS}

Comparison of the content of lysozyme in the egg white of hens of different genetic groups provides information on its occurrence depending on the origin of hens. The data indicate that lysozyme content is higher in the egg white of laying hens in comparison to meat lines. This may be of practical importance with respect to the use of eggs of laying hens to obtain more of this enzyme for use in the food industry, veterinary medicine or pharmacology.

\section{REFERENCES}

Abeyrathne E.D.N.S., Lee H.Y., Ahn D.U. 2013. Egg white proteins and their potential use in food processing or as nutraceutical and pharmaceutical agents. A review. Poultry Sci. 92, 3292-3299.

Aviagen EPI B.V. 2012. Aspekty zarządzania brojler Ross 308 [Aspects of management of Ross 308 broilers]. Aviagen, Netherlands. [in Polish]

Basmacioglu H., Ergul M. 2005. Research on the factors affecting cholesterol content and some other characteristics of eggs in laying hens. The effects of genotype and rearing system. Turk. J. Vet. Anim. Sci. 29, 157-164.

Bielecka M.M., Cichosz G., Nowak K. 2015. Sources of folates in human diet. Folia Pomer. Univ. Technol. Stetin., Agric., Aliment., Pisc., Zootech. 322(36)4, 15-28.

Bioactive egg compounds. 2007. Eds. R. Huopalahti, R. López-Fandiño, M. Anton, R. Schade. Berlin, Springer-Verlag.

Borowiak R., Leśnierowski G. 2012. Próba zwiększenia funkcjonalności preparatów otrzymanych metodą wysokotemperaturowej modyfikacji lizozymu [An attempt to increase the functionality of preparations obtained by high-temperature modification of lysozyme]. Żywność Nauka Technol. Jakość 5, 124-134. [in Polish]

Cegielska-Radziejewska R., Leśnierowski G., Kijowski J. 2003. Antibacterial activity of lysozyme modified by membrane technique. Electron. J. Pol. Agric. Univ., Food Sci. Technol. 6(2), 1-6.

Cegielska-Radziejewska R., Leśnierowski G., Kijowski J. 2009. Antibacterial activity of hen egg white lysozyme modified by thermochemical technique. Eur. Food Res. Technol. 228, 841-845.

Czaja L., Gornowicz E. 2006. Wpływ genomu oraz wieku kur na jakość jaj spożywczych [The effect of the genome and age of hens on the quality of table eggs]. Rocz. Nauk. Zootech. 33(1), 59-70. [in Polish]

Daeschel M.A., Bruslind L., Clawson J. 1999. Application of the enzyme lysozyme in brewing. MBAA TQ. 36, 219-222.

Gajda E., Bugla-Płaskońska G. 2014. Lizozym - występowanie w przyrodzie, właściwości biologiczne i możliwości zastosowań [Lysozyme - its occurrence in nature, biological properties, and potential applications]. Post. Hig. Med. Dośw. 68, 1501-1515. [in Polish] 
Gilewski R., Wężyk S. 2010. Wyposażenie pomieszczeń dla kur nieśnych i kurcząt mięsnych. Nowe trendy w hodowli i produkcji kur. Warszawa, O.W. „Hoża”. [in Polish]

Gołąb K., Warwas M. 2005. Białka jaja kurzego - właściwości biochemiczne i zastosowania [Chicken egg white - biochemical properties and applications]. Adv. Clin. Exp. Med. 14, 1001-1010. [in Polish]

Haas M., Moolenaar F., Meijer D.K., De Zeeuw D. 2002. Specific drug delivery to the kidney. Cardiovasc. Drugs Ther. 16, 489-496.

Hocking P.M., Bain M., Channing C.E., Fleming R., Wilson S. 2003. Genetic variation for egg production, egg quality and bone strength in selected and traditional breeds of laying fowl. Br. Poultry Sci. 44, 3, 365-373.

Hunton P. 2005. Research on eggshell structure and quality: An historical overview. Braz. J. Poultry Sci. 7, 67-71.

Jolles P., Jolles J. 1984. What is new in lysozyme research? Mol. Cell. Biochem. 63, 165.

Kijowski J., Leśnierowski G. 1995. Wykorzystanie lizozymu do utrwalania żywności w diagnostyce medycznej i farmakologii [The use of lysozyme to preserve food in medical diagnostics and pharmacology]. Biotechnologia 2, 130-140. [in Polish]

Kijowski J., Leśnierowski G. 1999. Separation, polimer formation and antibacterial activity of lysosyme. Pol. J. Food Nutrit. Sci. 8(49)3, 3-16.

Kijowski J., Leśnierowski G., Cegielska-Radziejewska R. 2013. Jaja cennym źródłem składników bioaktywnych [Eggs as a valuable source of bioactive nutrients]. Żywność Nauka Technol. Jakość 5(90), 29-41. [in Polish]

Krawczyk J. 2009. Effect of layer age and egg production level on changes in quality traits of eggs from hens of conservation breeds and commercial hybrids. Ann. Anim. Sci. 9(2), 185-193.

Krawczyk J., Gornowicz E. 2010. Quality of eggs from hens kept in two different free-range systems in comparison with a barn system. Arch. Geflügelk. 74(3), 151-157.

Leśnierowski G. 2007. Fizykochemiczne metody modyfikacji i pomiaru aktywności lizozymu. Poznań, AR, 5-15. [in Polish]

Leśnierowski G. 2009. Nowe sposoby fizykochemicznej modyfikacji lizozymu [New methods of physicochemical modification of lysozyme]. Nauka Przyr. Technol. 3/4, 130. [in Polish]

Leśnierowski G., Borowiak R. 2012. Wpływ warunków środowiskowych na zmianę właściwości lizozymu w białku jaj kurzych [The effect of environmental conditions on lysozyme properties in chicken egg white]. Żywność Nauka Technol. Jakość 3, 77-87. [in Polish]

Lewko L., Gornowicz E. 2009. Kształtowanie się jakości białka jaja w zależności od pochodzenia ptaka [Egg albumen quality as affected by bird origin]. J. Centr. Europ. Agric. 10(4), 455-464. [in Polish]

Lewko L., Gornowicz E. 2015. Żywienie ptaków - możliwości kształtowania się jakości białka jaja kurzego z uwzględnieniem właściwości lizozymu [Bird nutrition - possibilities of modifying the quality of hen's egg with consideration of lysozyme properties]. Wiad. Zootech. 53(4), 16-24. [in Polish]

Lewko L., Gornowicz E. 2016. Jakość jaj kurzych w zależności od ich kategorii wagowej [Quality of chicken eggs In relation to their weight category]. Rocz. Nauk. Pol. Tow. Zootech. 12(4), 85-94. [in Polish]

Liang A.H., Sugawara N., Ohno N., Adachi Y., Yadomae T. 1998. Effect of O-antigenic polysaccharide of Escherichia coli on endotoxin neutralizing activity of lysozyme. FEMS Immunol. Med. Microbiol. 21, 79-87.

Malicki A., Jarmoluk A., Brużewicz S. 2003. Wpływ dodatku lizozymu na trwałość i bezpieczeństwo mikrobiologiczne kiełbas w osłonce barierowej [The effect of the addition of lysozyme on the shelf life and microbiological safety of sausages in a barrier casing]. Acta Sci. Pol., Medicina Veterinaria 2, 29-36. [in Polish]

Masschalck B., Van Houdt R., Van Haver E.G.R., Michiels C.W. 2001. Inactivation of gram-negative bacteria by lysozyme, denatured lysozyme, and lysozyme-derived peptides under high hydrostatic pressure. Appl. Environ. Microbiol. 67, 339-344. 
Michalak K., Mróz E. 2003. Jakość białka jaja. Cz. II [Egg white quality. Part II]. Pol. Drob. 4, 9-10. [in Polish]

Mine Y., Ma F., Lauriau S. 2004. Antimicrobial peptides released by enzymatic hydrolysis of hen egg white lysozyme. J. Agric. Food Chem. 52, 1088-1094.

Rachwał A. 2006. Czynniki żywieniowe wpływające na wylęgowość jaj [Dietary factors influencing egg hatchability]. Pol. Drob. 3, 8-11. [in Polish]

Silversides F.G., Budgell K. 2004. The relationships among measures of egg albumen height, pH and whipping volume. Poultry Sci. 83, 1619-1623.

Smulikowska S., Rutkowski A. 2005. Normy żywienia drobiu. Jabłonna, IFiŻZ PAN. [in Polish]

Sokołowicz Z., Krawczyk J. 2004. Wpływ wieku kur i wielkości obsady na jakość jaj spożywczych [The effect of hen age and stocking density on the quality of table eggs]. Rocz. Nauk. Zootech. 31(1), 103-113. [in Polish]

Sophianopoulos A.J. 1969. Association sites of lysozyme in solution. J. Biol. Chem. 244, 3188-3193.

Szablewski T., Gornowicz E., Stuper-Szablewska K., Kaczmarek A., Cegielska-Radziejewska R. 2013. Skład mineralny treści jaj kur ras zachowawczych z chowu ekologicznego [The mineral composition of the egg contents of organically raised hens of protected breeds]. Żywność Nauka Technol. Jakość 5 (90), 42-51. [in Polish]

Trziszka T. 2000. Budowa i skład chemiczny jaja, w: Jajczarstwo. Red. T. Trziszka. Wrocław, AR, 147-188. [in Polish]

Williams K.C. 1992. Some factors affecting albumen quality with particular reference to Haugh unit score. World's Poultry Sci. J. 48(1), 5-16.

Yajima M., Hidaka Y., Matsuoka Y. 1968. Studies on egg-white lysozyme as a preservative of sake. J. Ferment. Technol. 46, 782-788.

\title{
PRAKTYCZNE ZASTOSOWANIE LIZOZYMU ORAZ JEGO ZAWARTOŚĆ W BIAŁKU JAJA KURZEGO
}

\begin{abstract}
Streszczenie. Celem pracy była analiza białka jaj kur linii Ross 308 , ze szczególnym uwzględnieniem lizozymu oraz możliwości jego zastosowania. Materiałem badawczym były jaja pochodzące ze stada rodzicielskiego kur typu mięsnego Ross 308. Przeprowadzono ocenę 200 jaj. Oceniano masę jaj, cechy białka oraz określano zawartość lizozymu w białku jaja. Na podstawie metaanalizy stwierdzono, że cechy jaj są zróżnicowane w poszczególnych grupach genetycznych. Badania własne dotyczyły kur mięsnych. Jaja pochodzące od tych kur, w porównaniu z kurami nieśnymi, charakteryzowały się większym udziałem żółtka i skorupy, a mniejszym białka. Zawartość lizozymu oznaczana w obu frakcjach białka łącznie wynosiła około $0,3 \%$. Można przypuszczać, że jaja kur linii nieśnych charakteryzują się nieco większą zawartością lizozymu, co może mieć znaczenie dla źródła jego pozyskiwania na potrzeby przemysłu.
\end{abstract}

Słowa kluczowe: białko jaja kurzego, lizozym. 
